\title{
The Role of Motility and Aerotaxis in the Selective Increase of Avirulent Bacteria in Still Broth Cultures of Pseudomonas solanacearum
}

\author{
By A. KELMAN AND JUDITH HRUSCHKA \\ Department of Plant Pathology, University of Wisconsin, Madison, \\ Wisconsin, 53706, U.S.A.
}

(Received 17 July 1972; revised 2 I November 1972)

\begin{abstract}
SUMMARY
A difference in relative motility between virulent and avirulent Pseudomonas solanacearum was a possible factor in the shift from virulent to avirulent populations in still broth cultures. Virulent isolates grown on solid media or in tryptone yeast-extract glucose or glycerol broth for 24 to $48 \mathrm{~h}$ were mainly non-flagellated or non-motile, whereas avirulent isolates grown under the same conditions were usually flagellated and highly motile. Fimbriae were observed in electron photomicrographs of both types. A rapid preferential increase of avirulent bacteria occurred when mixtures were grown in still, but not in shaken, broth cultures; this relative increase was greatest close to the surface of the medium. Rapid aerotaxis of avirulent bacteria was demonstrated in mixtures of virulent and avirulent bacteria in a semisolid motility agar medium. Positive aerotaxis and high motility apparently favoured rapid increase of avirulent $P$. solanacearum when oxygen became limiting in broth media, in which virulent bacteria were not actively motile.
\end{abstract}

\section{INTRODUCTION}

Rapid loss in virulence in certain culture media characterizes Pseudomonas solanacearum E. F. Smith, which causes destructive wilt diseases of many important solanaceous crops (Kelman, 1953). In non-aerated liquid media containing glucose and an organic source of nitrogen, attenuation correlates with the relatively rapid appearance of avirulent or weakly virulent variants (Kelman, I954, I956; Husain \& Kelman, I958). On a tetrazolium chloride medium, the irregularly round, fluidal colonies of virulent isolates can be readily distinguished from the small butyrous colonies of avirulent or weakly virulent isolates (B type) that do not form the extracellular polysaccharide characteristically formed by virulent bacteria (Kelman, 1954; Husain \& Kelman, 1958). Variants recognizable by colony type appear in cultures derived from single virulent bacteria (Kelman, 1954), but the genetic basis for this change in colony morphology has not been determined.

A wide range of factors has been shown to influence the similar shift from smooth (S) to rough $(\mathrm{R})$ colony types in populations of certain bacteria in non-aerated broth cultures (Braun, 1965). In recent studies with Pseudomonas solanacearum, none of the major factors associated with the shift in colony types in other bacteria could be directly related to that observed in non-aerated tryptone yeast-extract glucose (TYG) broth cultures of this pathogen. However, a virulent culture (25-K60) grown on the TZC medium was usually non-motile, whereas the avirulent $\mathrm{B}$ types of 25 - $\mathrm{K} 60$ were highly motile.

Motility presumably aids a bacterium to survive when nutrient and other essential factors such as oxygen become limiting (Carlson, 1962). Quantitative data in support of this concept 
have been presented by Old \& Duguid (1970, I97I) with motile and non-motile strains of Salmonella typhimurium as an adjunct to their detailed studies on selective growth of fimbriate over non-fimbriate bacteria in still culture. Similar observations were made by Smith \& Doetsch (1969) in experiments with motile and non-motile strains of Pseudomonas fluorescens.

The factors affecting chemotaxis of bacteria have been re-examined recently (Adler, $1966 a$ ), and the observations of early investigators on aerotaxis confirmed and extended (Sherris, Preston \& Shoesmith, 1957; Baracchini \& Sherris, 1959). Adler and co-workers (Adler, 1966 a, b, I969; Adler \& Dahl, 1967; Adler \& Templeton, 1967) developed improved quantitative techniques in their careful investigations of motility and chemotaxis of Escherichia coli. Certain of these techniques were found to be applicable for motility studies with Pseudomonas solanacearum.

This investigation was initiated to determine whether differences in motility between virulent and avirulent Pseudomonas solanacearum could be related to the population shifts in non-aerated broth cultures. Preliminary reports on parts of this study have been presented (Kelman \& Hruschka, I970, 1972).

\section{METHODS}

General procedures. The isolates of Pseudomonas solanacearum mainly used were (i) the virulent fluidal strain 25-K60 (Husain \& Kelman, I958), and (ii) BI-A, an avirulent culture of $25-\mathrm{K} 60$ (Table I). The avirulent isolate was obtained from a single colony of the butyrous variant type (B) selected from a dilution plating of a culture of $25-\mathrm{K} 60$ on tetrazolium chloride agar medium (TZC) (Kelman, I954), following growth of a pure clone of the virulent colony type in tryptone yeast-extract-glucose-broth (TYG) in a test tube for $96 \mathrm{~h}$ at $32{ }^{\circ} \mathrm{C}$. The TYG broth medium contained ( $\mathrm{g} / \mathrm{l}$ distilled water): tryptone (Difco, Detroit, Michigan, U.S.A.), Io; yeast extract (Difco), I; glucose, Io. Test isolates were stored as suspensions (approximately $\mathrm{I} \times 10^{7}$ bacteria $/ \mathrm{ml}$ ) in sterile double-distilled water $(5 \mathrm{ml})$ in tightly capped test tubes at approximately $20^{\circ} \mathrm{C}$ (Kelman \& Person, I96I). Isolates from other hosts and other geographic areas (Table I) were also examined; avirulent butyrous colony types of these isolates to be used in motility studies were obtained as described above.

Viable counts were made by surface plating on the TZC medium. Cultures were usually incubated at $32{ }^{\circ} \mathrm{C}$ for $48 \mathrm{~h}$.

Percentages of avirulent colony types in cultures were determined by either streaking dilute suspensions or making dilutions on TZC plates and examining colony characteristics with oblique lighting (Kelman, 1954; Husain \& Kelman, I958).

In greenhouse tests of relative virulence of cultures, tomato (Lycopersicon esculentum Mill.) and tobacco (Nicotiana tabacum L.) seedlings were stem-inoculated following procedures outlined by Winstead \& Kelman (1952).

Motility studies. Suspensions were prepared from cultures grown on TZC plates for 24 to $48 \mathrm{~h}$ or in TYG broth for $24 \mathrm{~h}$ at $32{ }^{\circ} \mathrm{C}$ and examined in hanging drops in distilled water, TYG broth, or the liquid motility medium (see below) at a 430 -fold magnification. Since it was difficult to determine exact percentages of motile bacteria in hanging drops, we used the following motility index scale: $0=$ no motile bacteria; $\mathrm{I}=$ less than $\mathrm{I} \%$; $2=\mathrm{I}$ to $\mathrm{IO} \% ; 3=\mathrm{II}$ to $50 \% ; 4=5 \mathrm{I}$ to $90 \%$; and $5=9 \mathrm{I}$ to $100 \%$.

Relative motility was also determined in semisolid agar plates following the procedure developed by Adler (1966a). The semisolid motility medium (SMM) contained: glucose, O.I g; tryptone (Difco), $0 . \mathrm{I} \mathrm{g}$; (ethylenedinitrilo) tetra-acetic acid disodium salt, $0.038 \mathrm{~g}$ 
(Adler \& Templeton, I967); Io $\mathrm{ml}$ of $\mathrm{pH} 7 \cdot 0$ phosphate buffer which provided $\mathrm{I} \cdot \mathrm{I} 77 \mathrm{~g}$ $\mathrm{K}_{2} \mathrm{HPO}_{4}$ and $0.44 \mathrm{I} \mathrm{g} \mathrm{KH}_{2} \mathrm{PO}_{4} / 1$ of medium; and $3.5 \mathrm{~g}$ agar (Difco)/1 distilled water.

To determine whether virulent bacteria that were initially non-motile when grown on TZC agar could become motile, suspensions were prepared in SMM without agar, incubated for 2 to $6 \mathrm{~h}$ at $32^{\circ} \mathrm{C}$, and then examined directly in hanging-drop preparations.

Following a procedure similar to that described by Vaituzis \& Doetsch (1969), motility track photographs of virulent and avirulent bacteria in water suspensions were taken with a Zeiss photomicroscope with Leica M-3 camera.

Electron microscopy. Electron photomicrographs were made with a JEM Model 7 electron microscope used at an accelerating voltage of $80 \mathrm{kV}$. Suspensions were washed in double-distilled filter-sterilized water, diluted with sterile $0.5 \%$ bovine serum albumin, placed on collodion-coated grids, freeze-dried over $\mathrm{CaCl}_{2}$, and shadowed with carbonplatinum pellets.

Aerotaxis experiments. To determine whether motile bacteria would show aerotaxis, SSM containing approximately I : I mixtures of virulent $(25-\mathrm{K} 60)$ : avirulent bacteria (BI-A) (approx. I $\times 10^{9}$ viable bacteria $\left./ \mathrm{ml}\right)$ was pipetted into sterile glass tubes $(5.5 \mathrm{~cm}$ long with an inner diam. of $2.5 \mathrm{~mm}$ ). These tubes were plugged at one end with hard agar and plasticine and open to the air at the other; were incubated upright, one set in air and the second in a container made oxygen-free by placing $3 \mathrm{ml}$ of $2.5 \mathrm{~N}-\mathrm{NaOH}$ and $0.3 \mathrm{~g}$ pyrogallol in a centre well and then flushing with nitrogen. After 6 to $\mathrm{I} 2 \mathrm{~h}$ at $32{ }^{\circ} \mathrm{C}$, the agar columns were extruded from the tubes by pushing up the basal plugs. Serial segments approximately I mm long were sliced with a razor from the agar column from the top down as the agar was extruded. Each segment was added to a water blank and percentage of avirulent bacteria determined by plating on TZC plates. Resazurin ( $1 \cdot 5 \mu \mathrm{g} / \mathrm{ml}$ final concn) was added to a series of control tubes with suspensions in the semisolid agar as an indirect means of monitoring oxygen levels.

\section{RESULTS}

Relative motility in hanging-drop preparations. The virulent isolate $25-\mathrm{K} 60$ was non-motile in hanging drops of suspensions prepared in sterile distilled water, TYG broth, or SMM minus agar. In contrast, BI-A and ten other avirulent B colony type cultures (also derived from $25-\mathrm{K} 60$ ) were actively motile (motility index, 3 to 4 ) when grown and observed under similar conditions. Similarly, 13 different virulent isolates $(203-215)$ obtained from North Carolina in 1969 also were mainly non-motile (motility index, o to I) when grown on TZC agar plates. In sharp contrast, the variant B colony types selected in platings from TYG broth cultures of each of these isolates were consistently highly motile (motility indices, 3 to 5) (Table I).

In cultures of several isolates [3 and 98 (banana), 19 (potato-Colombia), 80 (Solanum phureja-Colombia), 90 (tobacco-Brazil) and 147 (tobacco-Australia)], B type variants were not detected until after incubation for 5 to 9 days and then only very low numbers were present. The B type colony variants selected at random for testing from these isolates were non-motile. A large number of B type colony variants obtained from various virulent cultures from solanaceous hosts were examined for motility in the course of our studies; non-motile strains were only detected in a few subcultures of these B type cultures. Rapid preferential increase of non-motile B types was not observed in mixtures with $25-\mathrm{K} 60$ in still culture.

In the early phases of the work, all observations on motility were made using suspensions shortly after they were prepared in double-distilled water or TYG broth from 24 to 48 -h 
Table I. Motility of virulent and avirulent cells of different isolates of Pseudomonas solanacearum grown on tetrazolium chloride medium and examined in hanging drops

\begin{tabular}{|c|c|c|}
\hline Race* & Host & Isolate no. $\dagger$ \\
\hline I & Pepper & $29(\mathrm{KI} 32)$ \\
\hline I & Solanum nigrum & 96 (SNI96) \\
\hline I & Tobacco & 27 (KI05) \\
\hline I & Tobacco & $77(\mathrm{~B}-\mathrm{I})$ \\
\hline I & Tobacco & 90 (ENA57I) \\
\hline I & Tobacco & $147(0170)$ \\
\hline I & Tobacco & $\begin{array}{l}203-215 \\
(M 64-M 76)\end{array}$ \\
\hline I & Tomato & $25(\mathrm{k} 60)$ \\
\hline $\mathbf{I}$ & Tomato & $26(\mathrm{~K} 74)$ \\
\hline I & Tomato & $30(K \perp 36)$ \\
\hline I & Tomato & 84 (ST3) \\
\hline I & Tomato & 88 (ENA557) \\
\hline 2 & Banana & $3(5107)$ \\
\hline 2 & Banana & 98 (BIOO) \\
\hline 2 & Plantain & $70($ s2 10) \\
\hline 3 & Ginger & $151(092)$ \\
\hline 3 & Potato & 19 (s205) \\
\hline 3 & Potato & 134 (KI97) \\
\hline 3 & Potato & I 45 (OI 8a) \\
\hline 3 & Potato & $152(013 a)$ \\
\hline 3 & Potato & $153(0158)$ \\
\hline 3 & Potato & I98 (LB-6) \\
\hline 3 & Solanum phureja & $80(s 206)$ \\
\hline 3 & Tomato & $143(002 a)$ \\
\hline
\end{tabular}

$\quad$ Geographic area
Raleigh, North Carolina, U.S.A.
Costa Rica
Quincy, Florida, U.S.A.
Japan
Minas Gerais, Brazil
Queensland, Australia
North Carolina, U.S.A.

$\overbrace{\text { Virulent }}^{\text {Motility } \ddagger} \overbrace{\text { Avirulent }}$

Race designation following characteristics defined by Buddenhagen \& Kelman (1964).

+ Appreciation is expressed to the following who provided designated cultures : W. F. Dudman, 30 (K 136); J. S. Cole, I34 (KI97); I. Buddenhagen, 96 (SNI96), 98 (BIO0); M. Goto, 77 (B-I); A. C. Hayward, I47 (OI70), I 53 (OI 58); R. E. C. Layne, 84 (ST3); C. F. Hobbs, 88 (enA77), 90 (ENA57I); C. E. Main and Alice Hisada, 203 (M64) through 215 (M76); L. Sequeira, 3 (sI07), I9 (s205), 70 (s2 10), 80 (s206); and E. I. Zehr, 198 (LB-6). Cultures 25 (K60), 26 (K74), and 29 (K 132) were isolated by the senior author.

$\ddagger$ Motility was based on microscopic observations of suspensions in hanging drops containing approximately $\mathrm{I} \times 10^{6} \mathrm{c} / \mathrm{ml}$ made in sterile distilled water from cultures grown on TZC agar at $32{ }^{\circ} \mathrm{C}$ for $48 \mathrm{~h}$. $0=$ none or less than $1 \%$ actively motile; $+=$ more than $50 \%$ actively motile.

$\S$ This culture was isolated from an infected plant observed in a field in S.W. Ontario, Canada, planted with seedlings obtained from Climax, Georgia, U.S.A.

cultures grown on TZC agar plates. When hanging drops of virulent suspensions prepared in SMM (minus agar) were examined after $4 \mathrm{~h}$, a high percentage (motility index, 4 ) became actively motile. This also occurred in TYG broth after $4 \mathrm{~h}$, but bacteria were usually nonmotile after $\mathrm{I} 2$ to $\mathrm{I} 6 \mathrm{~h}$ in TYG broth.

Electron microscopy. Five to Io out of approximately 500 virulent $25-\mathrm{K} 60$ from i 8 to $24 \mathrm{~h}$ TZC agar cultures had flagella. In contrast, 80 to $85 \%$ of avirulent organisms had one or more polar flagella (Fig. I $b$ ).

Motile bacteria were obtained when suspensions of 25 - $\mathrm{K} 60$ were made in SMM (minus agar) for 3 to $4 \mathrm{~h}$. The flagella present usually appeared to be straight and shorter (Fig. I $a$ ) than those observed on motile avirulent bacteria. Other investigators have reported that bacteria with straight flagella were non-motile (Iino \& Mitani, I967; Iino, 1969).

The areas immediately adjacent to virulent bacteria appeared to boil for a few seconds after exposure to the electron beam. This was apparently an effect of high temperatures on their slime or extracellular polysaccharide. 


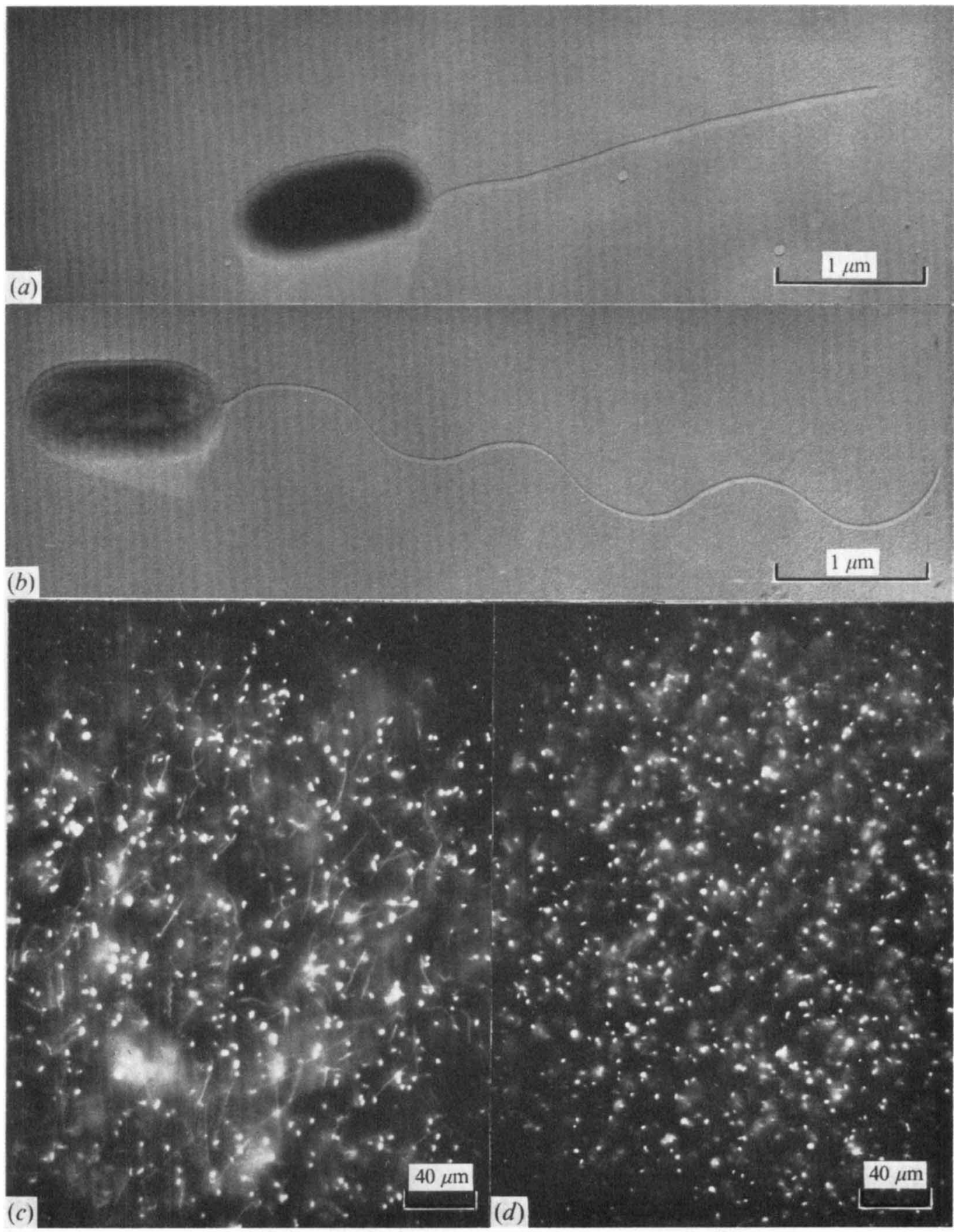

Fig. I. Electron photomicrographs of virulent $(a)$ and avirulent $(b)$ cells of Pseudomonas solanacearum showing flagella. Motility track photographs of a suspension of motile avirulent $(c)$ and non-motile virulent $(d)$ Pseudomonas solanacearum. Exposure time $=0.5 \mathrm{~s}$. 
Polar fimbriae were commonly present on 25-K60 and BI-A. Previously, Fuerst \& Hayward (1969) had observed polar fimbriae on biotypes II, III and IV of Pseudomonas solanacearum. The cultures (25-K60 and BI-A) examined by electron microscopy in this study belong to biotype I according to Hayward's classification (Hayward, 1964).

Motility track photography. Photographs of suspensions of the avirulent BI-A strain and the virulent $25-\mathrm{K} 60$ were taken shortly after suspensions were prepared from TZC plates. The distinct tracks made by actively motile BI-A are visible as white streaks on the dark background (Fig. I c). No tracks are evident in the preparations made with virulent organisms (Fig. I $d$ ). Velocity of the avirulent types, calculated from motility track lengths, was approximately $53 \mu \mathrm{m} / \mathrm{s}$ or 34 lengths/s, very similar to values obtained from motility tracks of Pseudomonas aeruginosa (Vaituzis \& Doetsch, 1969).

Population trends in broth cultures. Variants did not appear in TYG broth cultures of the virulent $25-\mathrm{K} 60$ grown on a shaker, whereas variants appeared and increased rapidly in still cultures (Kelman, 1956). If aerotaxis and/or differences in motility were involved in this rapid increase at limiting oxygen levels, one could expect to find more variants near the surface of the medium in still cultures of mixtures of virulent and avirulent types.

Cultures were sampled at the surface and at different levels below the surface of TYG broth containing $0.075 \mathrm{~g}$ Difco agar/l to minimize the effect of movement of medium. The agar also reduced rate of diffusion of oxygen. Suspensions $\left(\mathrm{I} \times 10^{8} / \mathrm{ml}\right)$ of $25-\mathrm{K} 60$, B I-A and a mixture of $25-\mathrm{K} 60$ with BI-A in the ratio of $100: \mathrm{I}$ were prepared in $10 \mathrm{ml}$ portions in test tubes. Resazurin was added in one series of test tubes. As had been observed in a preliminary experiment using broth media, no motile bacteria were present in the surface layer of cultures of $25-\mathrm{K} 60$ alone at $12 \mathrm{~h}$, and less than $\mathrm{I} \%$ were motile at $24 \mathrm{~h}$. In marked contrast, BI-A organisms were still actively motile after $48 \mathrm{~h}$ (motility index, 4 to 5 ). In the mixture series, the number of motile bacteria increased rapidly and at $48 \mathrm{~h}$ the motility index was 4 . The percentage of $\mathrm{B}$ type colonies in streaked plates from the mixture was $68 \%$; thus, the ratio of $25-\mathrm{K} 60$ :BI-A shifted from I00: I to approximately $\mathrm{I}: 2$ during this period. This shift was attributable to the preferential increase of the BI-A population rather than the development of other B type variants from $25-\mathrm{K} 60$, since the percentage of avirulent colonies in streaked plates of 25-K60 alone was about I \% after $48 \mathrm{~h}$.

With BI-A alone, a distinct layer or band of growth appeared several $\mathrm{mm}$ below the surface of the medium. The position of this band indicated that the high levels of $\mathrm{O}_{2}$ at the medium/air interface may be inhibitory. This effect has been observed previously with other pseudomonads (Baracchini \& Sherris, 1959).

Observations on the patterns of distribution of oxidized resazurin indicated that the population shift had occurred during the period when oxygen concentrations in the medium had decreased to a level limiting growth except close to the surface.

To determine the influence of aeration on motility of $25-\mathrm{K} 60$ and BI-A, TYG broth was dispensed in $25 \mathrm{ml}$ samples into $\mathrm{I} 25 \mathrm{ml}$ flasks. Initial populations were $10^{7}$ bacteria $/ \mathrm{ml}$; three flasks of each isolate were placed on a rotary shaker and three were incubated without aeration. Motility was determined at $8,19,25$ and $96 \mathrm{~h}$. Percentage motility of 25-K60 was low in the shaken (motility index $=2$ ) and non-shaken flasks (motility index, 2) at $8 \mathrm{~h}$ and zero at I9 and $25 \mathrm{~h}$. In contrast, $90 \%$ or more of the BI-A series (shaken or non-shaken) were actively motile at 8 and $19 \mathrm{~h}$; motility declined only slightly after $25 \mathrm{~h}$. After the initial growth period, no motile organisms were detected in the shake flasks of $25-\mathrm{K} 60$, even after 8 days; furthermore, no mutant B colony types appeared in the streakings made on TZC agar. In marked contrast, motile bacteria were detected after 4 days in the non-shaken flasks and could be directly correlated to the percentage of variant $B$ type colonies on 
Table 2. Relative growth of virulent (25-K60) and avirulent (BI-A) Pseudomonas solanacearum alone and in a mixture in still and shaken cultures*

\begin{tabular}{|c|c|c|c|c|}
\hline \multirow[b]{3}{*}{ Culture } & \multicolumn{4}{|c|}{$\begin{array}{l}\text { Viable bacteria }\left(\times 10^{7}\right) / \mathrm{ml} \\
\text { Growth period }(\mathrm{h})\end{array}$} \\
\hline & \multicolumn{2}{|c|}{24} & \multicolumn{2}{|c|}{48} \\
\hline & Still & Shaken & Still & Shaken \\
\hline $25-\mathrm{k} 60$ & 20 & 72 & 90 & 1500 \\
\hline BI-A & 26 & 79 & 180 & 2000 \\
\hline Mixture of $25-\mathrm{K} 60: \mathrm{BI}-\mathrm{A}$ & & & & \\
\hline $25-\mathrm{K} 60$ & 19 & 66 & 90 & 1200 \\
\hline BI-A & $3 \cdot 6$ & $7 \cdot 5$ & I 20 & 280 \\
\hline
\end{tabular}

$*$ Growth medium $=$ TYG broth, $25 \mathrm{ml} / 250 \mathrm{ml}$ flask, incubated at $30{ }^{\circ} \mathrm{C}$. Initial populations of $25-\mathrm{K} 60$ and $\mathrm{BI}-\mathrm{A}$ grown separately $=1 \times 10^{5} \mathrm{ml}$; in mixture $25-\mathrm{K} 60=$ approx. $9 \times 10^{4}$ and $\mathrm{BI}-\mathrm{A}=\mathrm{I} \times 10^{4} \mathrm{ml}$.

Table 3. Percentage increase in diameter of bacterial migration zones of virulent (25-K60) and avirulent (BI-A) Pseudomonas solanacearum on semisolid motility agar plates with different nitrogen sources

\begin{tabular}{|c|c|c|c|c|c|}
\hline \multirow[b]{2}{*}{ N source } & \multirow[b]{2}{*}{$\begin{array}{l}\text { Concentration } \\
(\mathrm{g} / \mathrm{l})\end{array}$} & \multicolumn{3}{|c|}{$\begin{array}{l}\text { Increase in diameter of } \\
\text { migration zones }(\%)^{*}\end{array}$} & \multirow{2}{*}{$\begin{array}{l}\text { Avirulent at outer } \\
\text { edge of migration } \\
\text { zone in mixture } \\
\text { plates }(\%)\end{array}$} \\
\hline & & Virulent & Avirulent & $\begin{array}{c}\text { Mixture }(\mathrm{I}: \mathrm{I}), \\
\text { virulent : avirulent }\end{array}$ & \\
\hline Ammonium chloride & 0.50 & 0 & 67 & I33 & 100 \\
\hline Ammonium nitrate & 0.74 & 0 & 102 & 133 & 100 \\
\hline Asparagine & 0.61 & 0 & 267 & 217 & 100 \\
\hline Casamino acids & $I \cdot 3$ & o & 233 & 167 & 100 \\
\hline Peptone & 0.8 & 0 & 267 & 283 & IOO \\
\hline Tryptone & $I \cdot O$ & 0 & 217 & 200 & 100 \\
\hline
\end{tabular}

* Based on average diameter of migration zones in three plates; initial diameters of inoculum drops $=$ $7 \pm \mathrm{I} \mathrm{mm}$; measurements after $20 \mathrm{~h}$ at $32^{\circ} \mathrm{C}$.

streaked plates. This pattern was duplicated when this experiment was repeated with 25-K60 and with five other virulent isolates from North Carolina (203, 205, 209, 21 2, 214). Lack of aeration per se was thus not the primary factor determining motility of virulent 25-K60 in TYG broth. However, lack of aeration was correlated with appearance and rapid increase of the B colony type variants in the non-aerated cultures of $25-\mathrm{K} 60$, as had been noted many times previously.

In a similar experiment, viable counts were made of $25-\mathrm{K} 6 \mathrm{O}$, BI-A and a mixture of 25-K60:BI-A (in ratio of 9: I), grown in TYG broth in still and shake culture. Viable counts from shake cultures of $25-\mathrm{K} 60$ and BI-A after 24 and $48 \mathrm{~h}$ were similar (Table 2). However, in the mixture in still cultures the population of BI-A increased from $3.6 \times 10^{7}$ at $24 \mathrm{~h}$ to $\mathrm{I} \cdot 2 \times 10^{9}$ at $48 \mathrm{~h}$, a 33 -fold increase. These data provided further evidence that the competitive ability of the motile BI-A was superior to that of $\mathrm{K}-60$ in still culture.

Migration in SMM plates. The relative motility of $25-\mathrm{K} 60$ was compared with that of BI-A in SMM in plates with the following nitrogen sources: tryptone, peptone, Difco Casamino acids, asparagine, ammonium nitrate and ammonium chloride. A single drop containing approximately $\mathrm{I} \times \mathrm{IO}^{8}$ bacteria was placed in the centre of each Petri plate. Suspensions used included a I: I mixture of BI-A:25-K60, BI-A alone, and 25-60 alone.

After $20 \mathrm{~h}$, the diameter of the migration zone of $\mathrm{BI}-\mathrm{A}$ had increased from $6 \mathrm{~mm}$ 


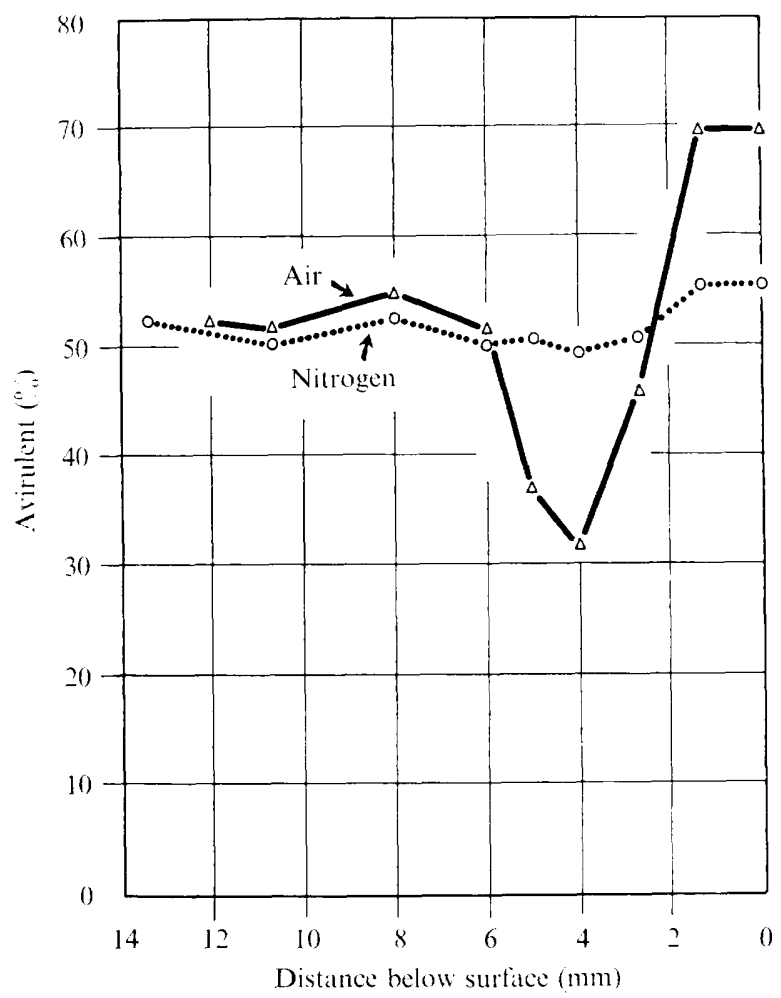

Fig. 2. Relative percentage of avirulent cells of Pseudomonas solanacearum in serial segments taken from surface downwards in semisolid motility agar in glass tubes $(5.5 \mathrm{~cm}$ long with inner diam. of $2.5 \mathrm{~mm}$ ) $6 \mathrm{~h}$ after incubation at $32{ }^{\circ} \mathrm{C}$ in air or in nitrogen. Ratio of avirulent: virulent bacteria $=$ $46 \%: 54 \%$ in the suspension added to the semisolid agar at the time tubes were filled.

(diameter of inoculum drop) to $22 \mathrm{~mm}(\%$ increase $=267)$, with peptone or asparagine as the $\mathrm{N}$ source (Table 3 ). No detectable migration band was formed by 25 - $\mathrm{K} 60$ during this period. In the plates containing I I mixtures of $25-\mathrm{K} 60: \mathrm{BI}-\mathrm{A}$, the increase in diameter of migration zones was attributable to the $\mathrm{BI}-\mathrm{A}$ component; streakings of samples taken from the edges of the migration zones contained only BI-A. Migration of BI-A in plates containing inorganic nitrogen was markedly less rapid than in plates containing organic sources of $\mathrm{N}$.

Avirulent B type bacteria in cultures of various isolates could be detected if distinct migration bands became evident 24 to $48 \mathrm{~h}$ after drops of suspensions were placed on the motility medium. Streakings of samples from the edge of the migation zone usually revealed that the B type was present. In those instances in which pure clones of $25-\mathrm{K} 60$ were used (suspensions from single well-isolated colonies from 36 to $48 \mathrm{~h}$ TZC plates), migration bands were usually not evident until after 48 to $72 \mathrm{~h}$.

Aerotaxis studies. At zero time in a typical experiment, the ratio of virulent $(25-\mathrm{K} 60)$ to avirulent (BI-A) was 47:53, and the viable count in the suspension added to the tubes was $9.8 \times 10^{8}$ bacteria $/ \mathrm{ml}$. At the end of $6 \mathrm{~h}$, the viable count in the top $\mathrm{I} \mathrm{mm}$ of agar was $15.5 \times 10^{8}$ bacteria $/ \mathrm{ml}$ indicating that growth and/or migration to the air interface had occurred during the test period.

The percentage of avirulent type in segments taken in descending order from top to 
Table 4. Motility and percentage avirulent B type present in surface samples of tryptone yeast extract broth tubes containing glucose or glycerol

\begin{tabular}{|c|c|c|c|c|c|}
\hline \multirow[b]{2}{*}{ Cultures tested } & \multirow{2}{*}{$\begin{array}{l}\text { Incubation } \\
\text { period } \\
\text { (h) }\end{array}$} & \multicolumn{2}{|c|}{ Motility index* } & \multicolumn{2}{|c|}{$\begin{array}{l}\text { Percentage B type } \\
\text { colony present }\end{array}$} \\
\hline & & Glucose & Glycerol & Glucose & Glycerol \\
\hline $25-\mathrm{K} 60$ & $\begin{array}{r}0 \\
26\end{array}$ & $\begin{array}{l}0 \\
0\end{array}$ & $\begin{array}{l}0 \\
0\end{array}$ & $\begin{array}{l}0 \\
0\end{array}$ & $\begin{array}{l}0 \\
0.5\end{array}$ \\
\hline BI-A & $\begin{array}{r}0 \\
26\end{array}$ & $\begin{array}{l}5 \\
4\end{array}$ & $\begin{array}{l}5 \\
4\end{array}$ & $\begin{array}{l}100 \\
100\end{array}$ & $\begin{array}{l}100 \\
100\end{array}$ \\
\hline $\begin{array}{l}\text { Initial mixture of } 25-\mathrm{K} 60: \mathrm{BI}-\mathrm{A} \\
\text { in ratio } 25: \mathrm{I}\end{array}$ & $\begin{array}{r}0 \\
26\end{array}$ & $\begin{array}{l}1 \\
3\end{array}$ & $\begin{array}{l}I \\
4\end{array}$ & $\begin{array}{r}4 \\
44\end{array}$ & $\begin{array}{r}4 \\
60\end{array}$ \\
\hline
\end{tabular}

* Based on estimates of percentages of motile bacteria in hanging drops according to following index scale: $0=$ none; $I=$ less than $\mathrm{I} \% ; 2=\mathrm{I}$ to $10 \% ; 3=\mathrm{II}$ to $50 \% ; 4=5 \mathrm{I}$ to $90 \% ; 5=9 \mathrm{I}$ to $100 \%$. Initial populations for $25-\mathrm{K} 60$ and $\mathrm{BI}-\mathrm{A}=4 \times 10^{5} \mathrm{ml}$. Suspensions prepared from cultures grown on TZC plates for $48 \mathrm{~h}$ at $32{ }^{\circ} \mathrm{C}$.

bottom in the tubes in the nitrogen atmosphere showed no distinct migration pattern (Fig. 2). In the tubes in air, however, the percentage of BI-A in the top segment had increased to $70 \%$, whereas in the third segment they had decreased to $32 \%$ from the original level of $53 \%$. In the lower sections, the percentage of BI-A in the population was 52 to $55 \%$. These data indicate that positive aerotaxis occurred and that the avirulent type moved more rapidly than the virulent to the zone close to surface. In control tubes containing resazurin, there was little or no colour at the surface of the agar in the nitrogen series, whereas a distinct pink colour extended to 3 to $4 \mathrm{~mm}$ in the tubes in the air. After $6 \mathrm{~h}$, a distinct band of massed bacteria appeared just below the meniscus of the SMM in the tubes containing BI-A alone and a clear zone was evident below; 25-K60 formed no such band. Similar visual evidence for positive aerotaxis of the BI-A was obtained when these experiments were repeated with $\mathrm{NH}_{4} \mathrm{NO}_{3}$ substituted for tryptone in the SMM.

Effect of carbon source on motility. Synthesis of flagella in a motile strain of Escherichia coli was inhibited by glucose (Adler \& Templeton, 1967); inhibition was related to decrease in levels of cyclic adenosine-3,5-monophosphate (cyclic AMP) (Yakota \& Gots, 1970) and was overcome by added cyclic AMP (Dobrogosz \& Hamilton, I97I). In our studies, glucose did not inhibit synthesis of flagella by the avirulent form of Pseudomonas solanacearum; however, the possibility existed that glucose could affect motility of the virulent form. If glucose repression of one or more enzyme systems (including those involved in flagella synthesis) occurs in $25-\mathrm{K} 60$ and not in BI-A, the generation time of $25-\mathrm{K} 60$ should presumably be shorter than that of BI-A in glucose. Relative growth rates of $25-\mathrm{K} 60$ and $\mathrm{BI}-\mathrm{A}$ were determined in TYG broth and in the same medium with glycerol substituted for glucose. Cultures were grown in $25 \mathrm{ml}$ of medium $/ 250 \mathrm{ml}$ flask incubated in a water-bath shaker at $32{ }^{\circ} \mathrm{C}$. Initial populations were approximately $10^{5}$ bacteria $/ \mathrm{ml}$. Viable counts were made at 2 to $3 \mathrm{~h}$ intervals over $\mathrm{I} 3 \mathrm{~h}$. The mean generation times were $57 \mathrm{~min}$ for $25-\mathrm{K} 60$ and $56 \mathrm{~min}$ for BI-A in tryptone yeast-extract-glucose and 68 and $72 \mathrm{~min}$ respectively in the glycerol medium.

The motility of $25-\mathrm{K} 60$ alone and in mixtures with BI-A was examined in tryptone-yeast extract broth with $10 \mathrm{~g}$ of either glucose or glycerol/1. No motile $25-\mathrm{K} 60$ was observed in hanging-drop suspensions prepared from samples taken close to the surface of either medium after $26 \mathrm{~h}$ (Table 4). In contrast, the BI-A cultures were actively motile, both initially and after $26 \mathrm{~h}$. In the series containing a 25 : I mixture of $25-\mathrm{K} 60$ with BI-A, the 
percentage of motile bacteria increased markedly over $26 \mathrm{~h}$. Furthermore, the ratio of $25-\mathrm{K} 60$ to BI-A shifted from $25: \mathrm{I}$ to $\mathrm{I} \cdot 37: \mathrm{I}$ in glucose and $0 \cdot 67: \mathrm{I}$ in the glycerol series. These observations confirm the rapid preferential increase of BI-A in mixed cultures with $25-\mathrm{K} 60$ when grown in still culture (Table 2). After 48 to $72 \mathrm{~h}$, the rate of appearance of B type variants from $25-\mathrm{K} 60$ in broth containing glycerol was similar to that observed in cultures with glucose.

Further evidence that a glucose effect was not involved in low motility of 25 -K60 was obtained in an experiment to determine relative motility of $25-\mathrm{K} 60$ and BI-A when grown on two different solid media: (i) the peptone $(\mathrm{I} \% \mathrm{w} / \mathrm{v})$-Casamino acids $(0 \cdot \mathrm{I} \%, \mathrm{w} / \mathrm{v})$ agar, and (ii) tryptone (I \% w/v) yeast-extract $(0.3 \%$ w/v) agar containing either glucose or glycerol or without either. No motile $25-\mathrm{K} 60$ was observed in hanging drops of suspensions prepared following growth for $20 \mathrm{~h}$ on these various media. In contrast, BI-A from all the media was actively motile. There were no apparent differences in relative motility that could be related to presence or absence of glucose or glycerol. Relative motility of test cultures in TYG broth or migration in SMM containing filter-sterilized glucose were essentially the same as in these media with autoclaved glucose.

Influence of temperature on motility. Temperatures at or above the optimum for growth may induce development of non-motile or non-flagellated forms of many motile bacteria (Kerridge, I96I ; Doetsch \& Hageage, 1968). Relative motility of Escherichia coli was also greater if organisms were grown at 24 to $25^{\circ} \mathrm{C}$ rather than at $37{ }^{\circ} \mathrm{C}$ (Adler \& Templeton, 1967). The optimum for growth of Pseudomonas solanacearum is $32^{\circ} \mathrm{C}$ (Kelman, I953), and most of the experiments on growth and motility had been completed at this temperature.

To determine effect of optimal and suboptimal temperatures on motility in Pseudomonas solanacearum, suspensions of virulent isolates (25-K60, 204, 208 and $2 \mathrm{II}$ ) and one avirulent isolate (BI-A) were prepared from cultures grown for $48 \mathrm{~h}$ on TZC plates at $32{ }^{\circ} \mathrm{C}$. The suspensions $\left(5 \mathrm{ml}\right.$, containing approximately $\mathrm{I} \times 10^{6}$ bacteria $/ \mathrm{ml}$ of SMM minus agar) were placed in tubes and incubated for $30 \mathrm{~h}$ at $22^{\circ}$ and $32^{\circ} \mathrm{C}$. At $4 \mathrm{~h}$, relative motility was higher at $22{ }^{\circ} \mathrm{C}$ than at $32{ }^{\circ} \mathrm{C}$ for all isolates. After $24 \mathrm{~h}$, motility in suspensions at $32{ }^{\circ} \mathrm{C}$ was markedly reduced, but a relatively high percentage at $22{ }^{\circ} \mathrm{C}$ were still motile. At $30 \mathrm{~h}$, all the virulent bacteria were non-motile at $32{ }^{\circ} \mathrm{C}$ and slightly motile at $22{ }^{\circ} \mathrm{C}$. The motility indices for BI-A were 3 at $22^{\circ} \mathrm{C}$ and 2 at $32^{\circ} \mathrm{C}$ at $30 \mathrm{~h}$.

Virulence and physiological characteristics of test isolates. In a comparison involving key diagnostic characteristics of Pseudomonas solanacearum (Hayward, 1964), selected avirulent butyrous cultures (including BI-A) were essentially indistinguishable from the type species. When injected into tobacco leaves, BI-A and the other B type variants used elicited a typical hypersensitive reaction (Lozano \& Sequeira, I970).

None of the B type isolates from race I cultures induced wilting symptoms when stem inoculations were made in tobacco and tomato seedlings, whereas all those classified as virulent on the basis of colony morphology induced the typical disease syndrome. All the B type isolates elicited formation of a localized necrotic lesion in the stem at the point of inoculation at the leaf axil, as has been noted previously (Averre \& Kelman, I964).

\section{DISCUSSION}

This investigation provides evidence that rapid selective increase of avirulent versus virulent bacteria in still broth cultures of Pseudomonas solanacearum can be attributed to the high motility and capacity for aerotaxis of the avirulent forms. Thus they have a competitive advantage over non-motile virulent forms when oxygen and perhaps other factors 
may become limiting. At a time in the growth of a given culture when oxygen was becoming a limiting factor, the virulent types were usually no longer motile.

The difference in motility between virulent isolates and their avirulent variants was not restricted to isolates from the southeastern United States, but also characterized most isolates from solanaceous hosts in other areas of the world (Table I).

These observations on the competitive advantage provided by motility of avirulent bacteria are similar to results obtained by Smith \& Doetsch (1969) with Pseudomonas fluorescens. Also, Old \& Duguid (1970, 197I) concluded that the selective advantage of motility was a more important factor in the outgrowth of a given clone of Salmonella typhimurium than the presence of fimbriae. If both fimbriate and non-fimbriate cultures were motile, the fimbriate bacteria had a distinct selective advantage over bacteria lacking fimbriae. Since fimbriae were observed on both the virulent $(25-\mathrm{K} 60)$ and avirulent (BI-A) cultures they probably do not play a major role in selective growth of avirulent BI-A in still cultures.

Since the shift from virulent to avirulent types is relatively rapid in broth cultures, it is probable that many early observations by E. F. Smith and others on motility (Kelman, 1953) and electron photomicrographs of flagella (Hodgkiss, 1964) of Pseudomonas solanacearum may have been based on cultures containing motile avirulent bacteria.

In contrast to observations with Escherichia coli (Adler \& Templeton, I967; Yakota \& Gots, 1970), we found no direct evidence that glucose repressed either motility or chemotaxis of avirulent or virulent bacteria.

No references were found in the literature indicating that motility and aerotaxis were involved in the colony type changes ( $\mathrm{S}$ to $\mathrm{R}$ ) in other species of motile bacteria (Braun, 1965). A re-evaluation of such studies may be indicated in the light of related research by other investigators (Smith \& Doetsch, 1969; Old \& Duguid, 1970, 1971) and our own investigations.

This work was supported in part by National Science Foundation Grant GB8288, the Wisconsin Alumni Research Foundation, and the College of Agricultural and Life Sciences, University of Wisconsin, Madison. For helpful suggestions during the investigation we are grateful to C. D. Upper, J. Adler, D. Kerridge and L. Sequeira. We also acknowledge with appreciation assistance of P. H. Williams in preparation of motility track photomicrographs, of G. Gaard and G. de Zoeten for the electron photomicrographs, and of Diane Cuppels for certain laboratory studies.

\section{REFERENCES}

AdLer, J. (1966a). Chemotaxis in bacteria. Science, New York 152, 708-716.

ADLER, J. (1966 b). Effect of amino acids and oxygen on chemotaxis in Escherichia coli. Journal of Bacteriology 92, $12 \mathrm{I}-\mathrm{I} 29$.

AdLER, J. (1969). Chemoreceptors in bacteria. Science, New York 166, I 588-I 597.

ADLER, J. \& DAHL, M. M. (1967). A method of measuring the motility of bacteria and for comparing random and non-random motility. Journal of General Microbiology 46, I6I-I73.

Adler, J. \& Templeton, B. (1967). The effect of environmental conditions on the motility of Escherichia coli. Journal of General Microbiology 46, I75-183.

Averre, C. W., III \& Kelman, A. (1964). Severity of bacterial wilt as influenced by the ratio of virulent to avirulent cells of Pseudomonas solanacearum in inoculum. Phytopathology 54, 779-783.

Baracchini, O. \& Sherris, J. C. (I959). The chemotaxic effect of oxygen on bacteria. Journal of Pathology and Bacteriology 77, 565-574.

Braun, W. (1965). Bacterial Genetics, 2nd edn, p. 380. Philadelphia, Pennsylvania: W. B. Saunders. 
Buddenhagen, I. \& Kelman, A. (1964). Biological and physiological aspects of bacterial wilt caused by Pseudomonas solanacearum. Annual Review of Phytopathology 2, 202-230.

CARLSON, F. D. (1962). A theory of the survival value of motility. In Spermatozoan Motility. Edited by D. W. Bishop. Washington, D.C.: American Association for the Advancement of Science Publication 72 .

Dobrogosz, W. J. \& Hamilton, P. B. (1971). The role of cyclic AMP in chemotaxis in Escherichia coli Biochemical and Biophysical Research Communications 42, 202-207.

DoETSCH, R. N. \& HAGEAGE, G. J. (I968). Motility in procaryotic organisms: problems, points of view and perspective. Biological Reviews 43, 317-362.

Fuerst, J. A. \& Hayward, A. C. (1969). Surface appendages similar to fimbriae (pili) on Pseudomonas species. Journal of General Microbiology 58, 227-237.

HAYWARD, A. C. (1964). Characteristics of Pseudomonas solanacearum. Journal of Applied Bacteriology 27, $265-277$.

Hodgkiss, W. (1964). The flagella of Pseudomonas solanacearum. Journal of Applied Bacteriology 27, $278-280$.

Husain, A. \& KeLMAN, A. (1958). Relation of slime production to mechanism of wilting and pathogenicity of Pseudomonas solanacearum. Phytopathology 48, 155-165.

IINo, T. (1969). Genetics and chemistry of bacterial flagella. Bacteriological Reviews 33, 454-475.

Ino, T. \& Mitani, M. (1967). A mutant of Salmonella possessing straight flagella. Journal of General Microbiology 49, 8I-88.

Kelman, A. (1953). The bacterial wilt caused by Pseudomonas solanacearum: a literature review and bibliography. North Carolina Agricultural Experimental Station Bulletin 99, pp. 194.

Kelman, A. (1954). The relationship of pathogenicity of Pseudomonas solanacearum to colony appearance in a tetrazolium medium. Phytopathology 44, 693-695.

Kelman, A. (1956). Factors influencing viability and variation in cultures of Pseudomonas solanacearum (Abstr.), Phytopathology 46, I6-17.

Kelman, A. \& HruschKa, J. (1970). Relationship between motility and loss in virulence in Pseudomonas solanacearum (Abstr.). Phytopathology 6o, 1298.

Kelman, A. \& HruschKa, J. (1972). Differences in motility between virulent and avirulent cells of Pseudomonas solanacearum. Proceedings Third International Conference on Plant Pathogenic Bacteria, pp. 313-315. Edited by H. P. Mass Geesteranus. Wageningen: Centre for Agricultural Publishing and Documentation.

Kelman, A. \& Person, L. H. (196I). Strains of Pseudomonas solanacearum differing in pathogenicity to tobacco and peanut. Phytopathology 5I, I58-16I.

KERRIDGE, D. (1961). The effect of environment on the formation of bacterial flagella. Symposium of the Society for General Microbiology II, 4I-68.

Lozano, C. \& Sequeira, L. (1970). Differentiation of races of Pseudomonas solanacearum by a leaf infiltration technique. Phytopathology 6o, 833-838.

Old, D. C. \& Duguid, J. P. (1970). Selective outgrowth of fimbriate bacteria in static liquid medium. Journal of Bacteriology 103, 447-456.

Old, D. C. \& Duguid, J. P. (1971). Selection of fimbriate transductants of Salmonella typhimurium dependent on motility. Journal of Bacteriology ro7, 655-658.

Sherris, J. C., Preston, N. W. \& Shoesmith, J. C. (I957). The influence of oxygen and arginine on the motility of a strain of Pseudomonas sp. Journal of General Microbiology 16, 86-96.

Smith, J. L. \& Doetsch, R. N. (1969). Studies on negative chemotaxis and the survival value of motility in Pseudomonas fuorescens. Journal of General Microbiology 55, 379-391.

VAituzis, Z. \& DoETSCH, R. N. (1969). Motility tracks: technique for quantitative study of bacterial movement. Journal of Applied Microbiology 17, 584-588.

Winstead, N. N. \& Kelman, A. (1952). Inoculation techniques for evaluating resistance to Pseudomonas solanacearum. Phytopathology 42, 628-634.

YAKOTA, T. \& Gots, J. S. (1970). Requirement of cyclic adenosine $3^{\prime}, 5^{\prime}$ phosphate for flagella formation in Escherichia coli and Salmonella typhimurium. Journal of Bacteriology 103, 513-516. 